\title{
Gait and functionality following unilateral and bilateral hip replacement
}

\author{
Marcha e funcionalidade após artroplastia \\ unilateral e bilateral de quadril
}

\section{Marcha y funcionalidad después de la artroplastia unilateral y bilateral de cadera}

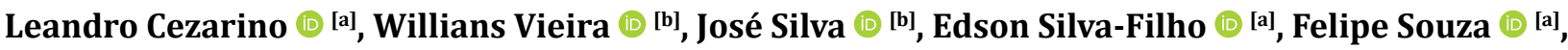 \\ Rodrigo Scattone $(\mathbb{1}$ [a]*
}

[a] Universidade Federal do Rio Grande do Norte (UFRN), Santa Cruz, RN, Brazil

[b] Universidade de Campinas (Unicamp), Campinas, SP, Brazil

\begin{abstract}
Introduction: Total Hip Replacement (THR) is a surgical procedure used to minimize symptoms generated by orthopedic pathologies, such as osteoarthritis. It is emphasized that there is no agreement if gait parameters are restored after surgery. Objective: To compare gait space-time and functionality between individuals submitted to unilateral or bilateral THR in relation to healthy controls. Method: A cross-sectional study was conducted with 23 subjects, eight submitted to Bilateral THR (BG), eight submitted to Unilateral THR (UG) and seven healthy individuals (CG). For the gait analysis, the 10-meter walk test was used, with the subjects walking in their Habitual (HS) and Maximal (MS) gait Speeds. Variables of interest included average speed, number of steps, test duration, cadence and Inter-Stride Time Variability (ISTV). Functionality was assessed by the Harris Hip Score and the WOMAC questionnaire. Comparisons were made between the three groups.
\end{abstract}

* ESF: PhD student, e-mail: meneses.edson@yahoo.com.br LC: MS, e-mail: leandrocezarino@yahoo.com.br WV: undergrad, e-mail: williansfvieira@gmail.com JS: undergrad, e-mail: josemegasi2@hotmail.com FS: MS, e-mail: f_heylan@hotmail.com RS: PhD, e-mail: r.scattone@outlook.com 
Results: At the HS condition, the average gait speed was significantly lower in the BG compared to the CG. Similarly, during the MS condition, the BG showed a lower gait speed compared to the CG. During MS gait, the BG performed significantly worse regarding ISTV compared to both the UG, and the CG. The functionality results showed that both the BG and UG scored significantly worse than the CG. Conclusion: Hip functionality and gait mechanics are impaired even after several years of surgery in subjects submitted to THR.

Keywords: Arthroplasty. Hip. Adult. Gait Analysis.

\section{Resumo}

Introdução: A Artroplastia Total de Quadril (ATQ) é um procedimento cirúrgico utilizado para minimizar sintomas gerados por patologias ortopédicas, como a osteoartrite. Ressalta-se que não há concordância se os parâmetros da marcha são restaurados após a cirurgia. Objetivo: Comparar os parâmetros espaço-temporais e funcionalidade da marcha entre indivíduos submetidos a ATQ unilateral ou bilateral, em relação aos controles saudáveis. Método: Estudo transversal com 23 sujeitos, oito submetidos à ATQ bilateral (BG), oito submetidos a ATQ unilateral (UG) e sete indivíduos saudáveis(GC). Para a análise da marcha, foi utilizado o teste de velocidade de marcha de 10 metros, com os sujeitos caminhando em suas velocidades de Marcha Habitual (HS) e Máxima (MS). As variáveis de interesse incluíram velocidade média, número de passos, duração do teste, cadência e Variabilidade Temporal Entre os Passos (ISTV). A funcionalidade foi avaliada pelo Harris Hip Score e o questionário WOMAC. Foram realizadas comparações entre os três grupos. Resultados: Na condição do HS, a velocidade média da marcha foi significativamente menor no grupo BG quando comparado ao GC. Da mesma forma, durante a condição de MS, o GB apresentou menor velocidade de marcha em relação ao GC. Durante a marcha MS, o BG teve um desempenho significativamente pior em relação ao ISTV em comparação tanto com o UG quanto com o GC. Os resultados de funcionalidade mostraram que tanto o BG como o UG tiveram pontuação significativamente pior que o GC. Conclusão: A funcionalidade do quadril e a mecânica da marcha estão prejudicadas mesmo após vários anos de cirurgia em indivíduos submetidos à ATQ.

Palavras-chave: Artroplastia. Quadril. Adulto. Análise da Marcha.

\section{Resumen}

Introducción: La Artroplastia Total de Cadera (ATC) es un procedimiento quirúrgico utilizado para minimizar los síntomas generados por patologías ortopédicas, como la osteoartritis. Se resalta que no hay concordancia si los parámetros de la marcha se restauran después de la cirugía. Objetivo: Comparar los parámetros espaciotemporales y la funcionalidad de la marcha entre individuos sometidos a ATC unilateral o bilateral, en relación a los controles sanos. Método: Estudio transversal con 23 sujetos, ocho sometidos a ATC bilateral (BG), ocho sometidos a ATC unilateral (UG) y siete individuos sanos (IS). Para el análisis de la marcha, se utilizó la prueba de velocidad de marcha de 10 metros, con los sujetos caminando en sus velocidades de Marcha Habitual (MH) y Máxima (MM). Las variables de interés incluyeron velocidad media, número de pasos, duración de la prueba, cadencia y Variabilidad Temporal Entre los Pasos (VTEP). La funcionalidad fue evaluada por Harris Hip Score y el cuestionario WOMAC. Se realizaron comparaciones entre los tres grupos. Resultados: En la condición de la $\mathrm{MH}$, la velocidad media de la marcha fue significativamente menor en el grupo BG cuando comparado al IS. De la misma forma, durante la condición de $M M$, el BG presentó menor velocidad de marcha en relación al IS. Durante la marcha MM, el BG tuvo un desempeño significativamente peor con respecto al VTEP en comparación con el UG y el IS. Los resultados de funcionalidad mostraron que tanto el BG como el UG tuvieron una puntuación significativamente peor que el IS. Conclusión: La funcionalidad de la cadera y la mecánica de la marcha están perjudicadas incluso después de varios años de cirugía en individuos sometidos a ATC.

Palabras clave: Artroplastia. Cadera. Adulto. Análisis de la Marcha. 


\section{Introduction}

Total Hip Replacement (THR) is one of the most common surgical procedures in many countries [1]. The benefits of this procedure include symptoms relief, functionality improvement and better quality of life in patients who have post-traumatic complications, hip dysplasia and severe degenerative hip disease, such as Osteoarthritis (OA) [2-5]. Functional deficits after THR may be caused by several factors, such as postural misalignment, leg length discrepancy, muscle weakness [6], surgical technique, surgical materials and inappropriate postoperative rehabilitation [7].

In this context, effort has been made to quantify outcomes related to THR. Less complex parameters of gait analysis, which have already been investigated after unilateral THR include stride length, cadency, gait speed and stance/balance time [8, 9]. Complex investigations, such as kinematic, kinetic, electromyographic and metabolic evaluations have also been described in this population [8-10]. These analyses can provide comprehensive data for research. However, they are time-consuming, expensive and difficult to apply in the clinical setting. In 2014, Kolk et al. [11] published an article with patients undergoing unilateral and bilateral THR using a simple and clinically reproducible gait analysis method.

A clinically available strategy of gait analysis consists of identifying biomechanical alterations in the gait pattern. Recently, Inter-Stride Gait Variability (ISGV) has attracted the attention of researchers since it is a good predictor of functional decline [1215]. However, researches about this gait parameters after THR, especially in patients who have undergone bilateral surgery, is still lacking. Functionality and symptoms severity have frequently been investigated by self-report measures, such as the Harris Hip Score (HHS) questionnaire and the Western Ontario and McMaster Universities Osteoarthritis Index (WOMAC) questionnaire $[16,17]$. In addition, the 10-meter walk test has also been used to evaluate gait function for people after THR [18]. Although, there are several studies about this thematic [19], a better understanding about recovery gait pattern function through clinical outcomes after THR is necessary.

From these assumptions, the purpose of this study was to compare space-time parameters and functionality gait using a clinically available tool and functionality, among subjects submitted to unilateral or bilateral THR, in relation to healthy controls.

\section{Methods}

This is a unicenter, quantitative and analytical cross-sectional study that included subjects aged 20 to 59 years who underwent THR more than six months before the beginning of the study and lived in the city of Campinas (São Paulo, Brazil). We adopted as exclusion criteria people who were submitted to surgery of the lower limbs (other than THR) or spine, complain of lower limb pain unrelated to THR, have incision-site infection, hip dislocation, prosthetic review, uncorrected leg length discrepancy greater than 1.5 centimeters, severe balance impairment, neurological, cardiovascular and/or musculoskeletal disorders, which prevented the subjects from walking. The primary indication of THR was hip osteoarthritis, followed by fracture and osteonecrosis of the femoral head. None of the subjects with bilateral hip replacement had both hips operated simultaneously.

The included participants were divided into two groups: Bilateral Group (BG - patients who underwent bilateral THR) and Unilateral Group (UG - patients who underwent unilateral THR). Asymptomatic young adults were recruited to compose the Control Group (CG). All procedures were performed consecutively in the Physiotherapy Department of the University of Campinas between the months of July and December, 2011. This study was approved by the ethical committee from the State University of Campinas (CAAE: 1106.0.146.000-11), followed by the resolution of the National Health Council (no 466/2012) and all the participants signed the written informed consent form. Initially the sociodemographic data were collected in a file created by the researchers and after that clinical tests were performed, such as Harris Hip Score, (HHS) Western Ontario and McMaster Universities Osteoarthritis Index (WOMAC) questionnaire and 10-Meter Walk Test. The HHS and WOMAC were filled out with assistance of the evaluators.

The HHS was used to assess hip function and symptoms severity [16]. This questionnaire has been translated and adapted to Brazilian Portuguese language [16] and consists of a 0-100 scale which scores pains, function and range of motion. The Brazilian Portuguese version of the WOMAC questionnaire $[17,20]$ was also used to quantify symptoms and disability in these patients. This questionnaire consists of a score including items to assess pain, joint stiffness and physical disabilities. 
Both of them were self-fulfilling and the researchers helped them, if necessary.

The 10-Meter Walk Test was used to evaluate gait, as previously described [18] and all individuals completed the test barefoot. A video camera (S760, Samsung, Varginha, BR) was positioned facing the midpoint of a $10 \mathrm{~m}$ walkway to record the test at a sampling frequency of $30 \mathrm{~Hz}$. Three markers were placed on each of the subject's feet with adhesive tape: one distal to the medial malleolus, one distal to the lateral malleolus and the third on the distal phalanx of the second toe. A chronometer (KD-1069, Kadio Electronics Com Ltd, Guangdong, CHI) was used to measure the time of each trial.

Two different walking conditions were adopted in the evaluations, Habitual Speed (HS) and Maximal Speed (MS), with the HS evaluation always preceding the MS. For the HS evaluation, subjects were asked to walk in the $10 \mathrm{~m}$ walkway at their habitual speed, as naturally as possible. For the MS evaluation, they were asked to walk as fast as they could, safely, and without running. The participants were allowed to use gait assistance devices, if necessary. The subjects were instructed to start each trial two steps before the start line and finish the test two steps after the finish line, to account for acceleration and deceleration during the task. Three trials of each walking condition were recorded, the average of them was calculated for analysis.

For data processing, an analysis system (VirtualDub - Copyright Avery Lee 1998-2009) was used in accordance with the protocol proposed by Kang and Dingwell [21]. Heel strike was defined as the moment when the inframalleolar marker of the lead limb was at the most forward position. Toe-off was defined as the most backward presentation of the second toe marker of the rear limb. Variables of interest included number of steps, test duration, cadency, average speed and Inter-Stride Time Variability (ISTV), all obtained, as previously described $[8,9]$.

To determine the stride-to-stride time variability over the entire gait cycle, means and Standard Deviations (SD) of each stride time were calculated at each percentage of the gait cycle. For each trial, the data for each stride were normalized from zero to $100 \%$ of the gait cycle. Data were analyzed without filtering because the goal was to examine gait space-time and functionality. Mean and SD were determined by the following equation:
$\operatorname{MeanSD}(\Delta \mathrm{x})=\{\operatorname{SDi}[(\Delta \mathrm{x})]\}=\{0-100 \%$ of the gait cycle\}, which SD indicates the standard deviation of a measure in $\%$ gait cycle, and " $\Delta \mathrm{x}$ " denotes the average over all values of " $i$ ". Where $\Delta x(i)=x(I+1)-x(i)$ [22].

Normality of data distribution was tested with the Shapiro-Wilk test. The Kruskal-Wallis test followed by the post hoc of Dunn was used to investigate differences of ISTV between groups. For the number of steps, test duration, cadency and average speed variables, one-way ANOVA followed by the post hoc of Tukey were used for group comparisons. The Prism 5.0 (GraphPad Software, San Diego,CA) was used for all data processing with a significance level $\leq 5 \%$.

\section{Results}

The flowchart of subjects' recruitment is shown in Figure 1. Twenty-eight subjects agreed to participate in this study. One patient from the BG was excluded for having one of the hips reconstructed twice. Four patients from the UG were excluded forbeing unable to walk independently ( $n=1)$, having recurrent prosthetic dislocations $(n=1)$, having leg length discrepancy greater than 1.5 centimeter $(n=1)$ and having underwent THR review $(n=1)$. The remaining 23 participants were included and their demographic characteristics, as well as the self-reported outcome measure scores, are represented in Table 1.

There were no demographic differences between groups. Subjects from the BG and the UG presented with significantly higher WOMAC scores compared to the $\mathrm{CG}(P<0.01)$. No difference was observed between the BG and the UG for this variable $(P>0.05)$. The HHS results showed that the BG scored significantly worse than the CG for both hips (first reconstructed hip, $P=0.029$; second reconstructed hip, $P=0.024$ ). No difference was found between the UG and the CG and between both hips of the BG in relation to UG $(P>0.05)$.

Table 2 shows the results of the 10-Meter Walk Test at both HS and MS regarding test duration, number of steps, cadency and average speed. At the HS condition, the average speed was significantly lower in the BG when compared to the CG $(P=0.05)$. Similarly, during the MS condition, the BG showed a lower speed compared to the CG $(P=0.01)$. The $\mathrm{BG}$ also took longer to complete the test than the CG $(P=0.03)$. For the variable number of steps and cadency, no differences were observed between groups $(P>0.05)$. 


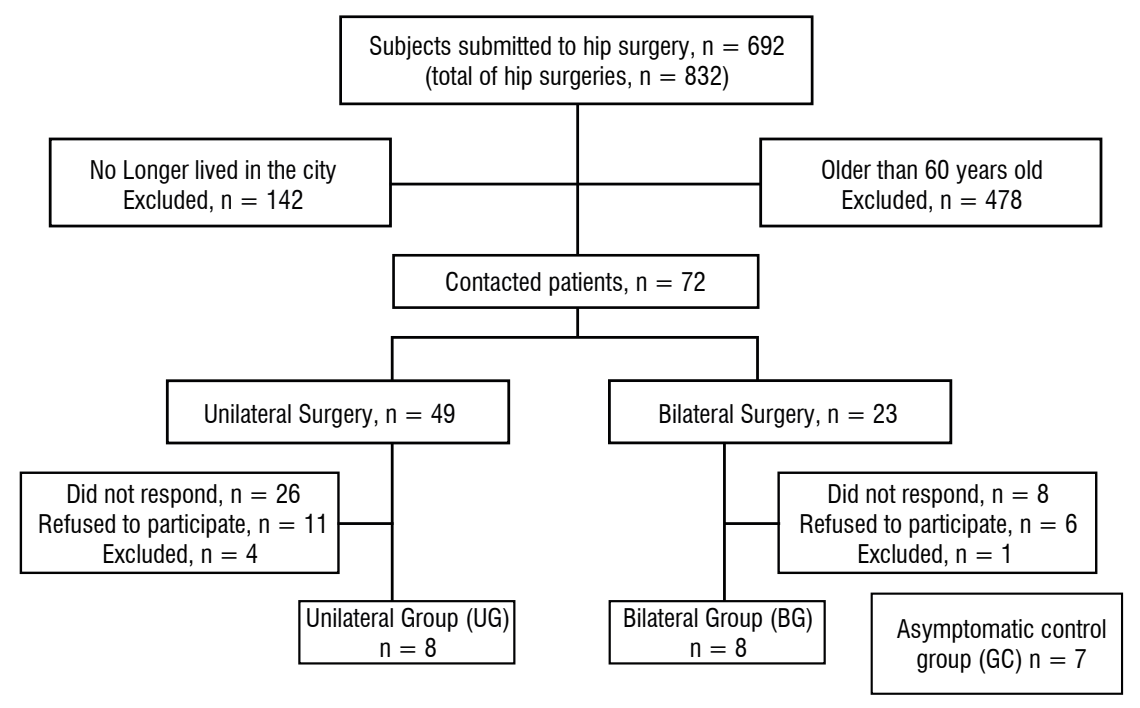

Figure 1-Overview of article selection process.

Table 1 - Subjects characteristics, Harris Hip Score (HHS) and Western Ontario and McMaster Universities Osteoarthritis Index (WOMAC) scores (mean \pm standard deviation)

\begin{tabular}{cccc}
\hline & BG $(\mathbf{n}=8)$ & UG $(\mathbf{n}=8)$ & CG $(\mathbf{n}=\mathbf{7})$ \\
\hline Gender (M/F) & $8 / 0$ & $5 / 3$ & $3 / 4$ \\
Age (years) & $51.87 \pm 7.97$ & $45.00 \pm 8.01$ & $45.85 \pm 7.31$ \\
Body mass (kg) & $84.04 \pm 15.71$ & $83.45 \pm 25.04$ & $74.41 \pm 11.21$ \\
Height (m) & $1.69 \pm 0.07$ & $1.70 \pm 0.10$ & $1.63 \pm 0.14$ \\
Body mass index (kg/m²) & $29.30 \pm 4.25$ & $28.42 \pm 6.95$ & $27.83 \pm 3.94$ \\
T1 (years) & $9.31 \pm 6.89$ & $6.54 \pm 4.06$ & $\mathrm{NA}$ \\
T2 (years) & $3.11 \pm 3.22$ & $\mathrm{NA}$ & $\mathrm{NA}$ \\
WOMAC & $26.00 \pm 25.74^{*}$ & $23.50 \pm 14.39^{*}$ & $2.57 \pm 6.80$ \\
HHS & $\mathrm{BG} 1=63.62 \pm 22.01^{*}$ & $73.56 \pm 13,43$ & $92.16 \pm 2.04$
\end{tabular}

Note: BG: Bilateral group; BG1: Bilateral Group (first reconstructed hip); BG2: Bilateral replacement (second reconstructed hip); UG: Unilateral Group; CG: Control Group; T1: Postoperative time of the first procedure; T2: Postoperative time of the second procedure; NA: not applicable. * Significant difference in relation to the $\mathrm{CG}(P<0.05)$.

Table 2 - Performance of the three groups in the $10 \mathrm{~m}$ Walk Test at the habitual and maximal gait speeds (mean \pm standard deviation)

\begin{tabular}{|c|c|c|c|c|c|c|}
\hline & \multicolumn{3}{|c|}{ Habitual Speed } & \multicolumn{3}{|c|}{ Maximum Speed } \\
\hline & BG & UG & CG & BG & UG & CG \\
\hline NS & $18.5 \pm 2.62$ & $17.50 \pm 2.14$ & $16.28 \pm 1.97$ & $15.50 \pm 2.16$ & $15.00 \pm 1.95$ & $13.57 \pm 1.98$ \\
\hline $\mathrm{T}(\mathrm{s})$ & $12.01 \pm 4.10$ & $10.23 \pm 1.67$ & $8.81 \pm 0.71$ & $8.86 \pm 3.17$ * & $7.63 \pm 1.63$ & $5.87 \pm 1.04$ \\
\hline Cad (NS/s) & $0.56 \pm 0.09$ & $0.57 \pm 0.07$ & $0.62 \pm 0.07$ & $0.65 \pm 0.09$ & $0.67 \pm 0.08$ & $0.75 \pm 0.10$ \\
\hline AS (m/s) & $0.9 \pm 0.27$ * & $0.99 \pm 0.14$ & $1.14 \pm 0.09$ & $1.22 \pm 0.36$ * & $1.36 \pm 0.24$ & $1.74 \pm 0.29$ \\
\hline
\end{tabular}

Note: BG: Bilateral replacement; UG: Unilateral replacement; CG: Control group; NS/s: Number of steps in seconds; $T$ (s): Duration of the test in seconds; Cad: Cadency; AS (m/s): Average speed in meter per seconds. ${ }^{*}$ Significant difference in relation to the $C G(P<0.05)$. 
Results of the ISTV coefficient are presented in Figure 2. During HS gait, the BG performed significantly worse than the CG, for this variable $(P<0.01$; Figure $2 \mathrm{~A})$. The median values of this variable were consistent among groups, although the median of the BG was much closer to the first quartile than to the third, demonstrating greater within-group variation. Comparisons between the BG and the UG, and between the UG and the CG

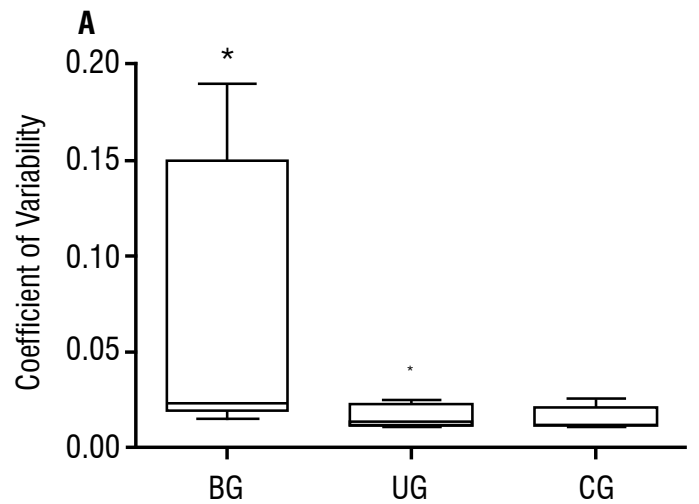

showed no significant differences $(P>0.05)$. During MS gait, the BG presented significantly higher ISTV compared to the UG, as well as to the CG $(P<0.01$; Figure 2B). Again, the median values of this variable were consistent among groups, although the median of the BG was much closer to the first quartile than to the third. No difference was observed between the UG and the CG for this variable $(P>0.05)$.

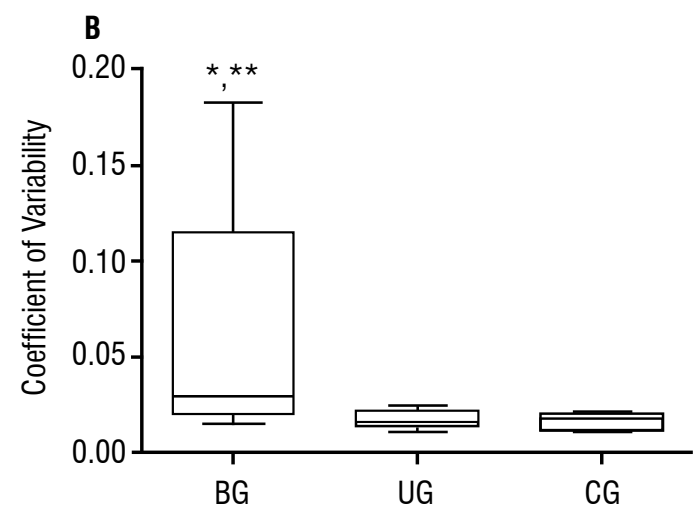

Note: (A) Habitual speed and (B) maximal speed. BG: Bilateral group; UG: Unilateral group; CG: Control group. *Significant difference between $B G$ and $C G ;{ }^{* *}$ Significant difference between $B G$ and UG.

Figure 2 - Inter-stride time variability coefficient.

\section{Discussion}

The current study aimed to analyze gait and functionality of young adults who underwent unilateral and bilateral THR, comparing them to a healthy CG. Outcomes were space-time gait parameters and self-reported functionality measures. Both replacement groups had worse functionality when compared to the CG. In addition, the BG had significantly lower gait speed and a higher coefficient of variation during gait (ISTV) when compared to the CG. Gait analyses in THR patients have been performed at six weeks, oneyear and 10-year follow-ups [8, 23, 24]. Significant improvements have been observed within the first year in terms of gait parameters. In the previously mentioned study by Brown et al. [10], at the one year follow-up, subjects with unilateral THR increased their average habitual gait speed from $0.68 \mathrm{~m} / \mathrm{s}$ to $0.91 \mathrm{~m} / \mathrm{s}$ (increase from $50 \%$ to $67 \%$ in relation to healthy subjects). However, despite the improvement observed within the first year after surgery, the authors observed that, at the followups of two-to-four years, the results of average speed, cadency and step length for the subjects with THR were considerably worse when compared to healthy subjects [10]. Our results indicate that even after many years of surgery, normalization of gait speed does not occur in subjects with bilateral THR compared to asymptomatic individuals.

Sicard-Rosembaum et al. [23] have observed similar results of average speed in relation to the ones found in the present study both at the habitual and maximal speeds in a slightly older population (60.2 \pm 15.0 years old). The Sao Paulo Company of Traffic Engineer (CET-SP) regulates the crossing time for pedestrians according to the crosswalk distance. The crossing time is calculated considering a walking speed of $1.2 \mathrm{~m} / \mathrm{s}(\mathrm{m} / \mathrm{s})$ [25]. The average gait speed observed in this study was higher than that value for the maximum speed of the BG and, slightly lower than that value for the UG. This indicates that an individual submitted to unilateral THR would need to walk at his/her maximal speed in order to cross a street safely, in addition people submitted to bilateral THR even walking at his/her maximal speed would not reach the minimal value to do it safely, which could lead to a higher risk of accidents. 
High coefficients of variability during gait represent fluctuation in the development of steps and are considered signs of gait instability $[26,27]$. In this context, Lindemann et al. [9] compared the average speed and step length variability pre and postoperatively among patients submitted to unilateral THR. The authors found that the postoperative results were better than the preoperative ones for these variables. Furthermore, a strong correlation was observed between these variables and the WOMAC score. However, to our knowledge, ISTV had not yet been studied in patients undergoing unilateral and bilateral THR. In the current study, ISTV was found to be higher among the BG compared to the CG at the HS condition. At the MS condition, the BG not only performed worse than the CG, but also than the UG regarding this variable. This suggests that individuals submitted to bilateral THR have greater gait instability, which could indicate that these subjects have a higher risk of falling.

A recent published systematic review has verified that, out of 67 self-reported outcome measures validated for THR patients, the WOMAC is one of the best-performing condition-specific tools to evaluate patients who have undergone hip surgery [28]. In the present study, both the BG and UG obtained higher WOMAC scores when compared to the CG. The results in this study indicate that both bilateral and unilateral THR patients present with impaired hip functionality compared to healthy individuals, even after several years of surgery.

In the present study, there was no difference between the replacement groups (BG vs UG) in the HHS score, however, both groups showed worse functionality when compared to the CG. In accordance to these findings, a previous study also found no difference regarding HHS outcomes between patients submitted to unilateral THR and bilateral THR [29]. Patients with hip dysplasia submitted to THR were recently evaluated with the HHS after 20 years of surgery, and it was observed that these patients had satisfying scores of functionality [30]. Still, the current literature lacks high quality studies comparing functional outcomes of patients submitted to unilateral and bilateral THR.

Some of this study's limitations need to be acknowledged. The small sample size might have prevented the identification of differences between groups for some of the evaluated variables. The absence of the sample calculation is also considered a limiting factor in this study. Besides, some sociodemographic data that may influence the results, which were not controlled, such as chronic diseases, psychosocial factors, the methods of fixation, the type of surgical access and the presence of comorbidities. Moreover, since a simple clinical tool was used for gait assessment, more complex analyses, such as step length were not possible. However, the use of gait variability parameters, as presented in this study, is relevant due to its large clinical applicability and its application as a predictor for functional decline.

\section{Conclusion}

Individuals undergoing bilateral THR showed lower average gait speed and greater gait variability when compared to a healthy CG. The BG also showed greater gait variability when compared to the UG at the MS condition. Finally, patients submitted to either unilateral or bilateral THR did not present functionality differences between each other. However, both groups were functionally worse than the CG. These results indicate that hip functionality and gait mechanics are impaired even after several years of surgery in subjects who underwent THR.

\section{References}

1. Chechik O, Khashan M, Lador R, Salai M, Amar E. Surgical approach and prosthesis fixation in hip arthroplasty world wide. Arch Orthop Trauma Surg. 2013;133(11):1595-600.

2. Wylde V, Blom AW, Whitehouse SL, Taylor AH, Pattison GT, Bannister GC. Patient-reported outcomes after total hip and knee arthroplasty: comparison of midterm results. J Arthroplasty. 2009;24(2):210-6.

3. Kennedy DM, Stratford PW, Hanna SE, Wessel J, Gollish JD. Modeling early recovery of physical function following hip and knee arthroplasty. BMC Musculoskelet Disord. 2006; 7:100.

4. Nantel J, Termoz N, Vendittoli PP, Lavigne M, Prince F. Gait patterns after total hip arthroplasty and surface replacement arthroplasty. Arch Phys Med Rehabil. 2009;90(3):463-9. 
5. Bennett D, Humphreys L, O’Brien S, Kelly C, Orr JF, Beverland DE. Gait kinematics of age-stratified hip replacement patients-A large scale, long-term followup study. Gait Posture. 2008;28(2):194-200.

6. Bozic KJ, Kurtz SM, Lau E, Ong K, Vail TP, Berry DJ. The epidemiology of revision total hip arthroplasty in the United States. J Bone Joint Surg Am. 2009;91(1):128-33.

7. Madsen MS, Ritter MA, Morris HH, Meding JB, Berend ME, Faris PM, et al. The effect of total hip arthroplasty surgical approach on gait. J Orthop Res. 2004;22(1):44-50.

8. Queen RM, Butler RJ, Watters TS, Kelley SS, Attarian DE, Bolognesi MP. The effect of total hip arthroplasty surgical approach on postoperative gait mechanics. J Arthroplasty. 2011;26(6 Suppl):66-71.

9. Lindemann U, Becker C, Unnewehr I, Muche R, Aminin K, Dejnabadi $\mathrm{H}$, et al. Gait analysis and WOMAC are complementary in assessing functional outcome in total hip replacement. Clin Rehabil. 2006;20(5):413-20.

10. Brown M, Hislop HJ, Waters RL, Porell D. Walking efficiency before and after total hip replacement. Phys Ther. 1980;60(10):1259-63.

11. Kolk S, Minten MJ, van Bon GE, Rijnen WH, Geurts AC, Verdonschot N, et al. Gait and gait-related activities of daily living after total hip arthroplasty: a systematic review. Clin Biomech. 2014;29(6):705-18.

12. Brach JS, Berlin JE, VanSwearingen JM, Newman AB, Studenski SA. Too much or too little step width variability is associated with a fall history in older persons who walk at or near normal gait speed. J Neuroeng Rehabil. 2005;2:21.

13. Brach JS, Studenski SA, Perera, S. VanSwearingen JM, Newman AB. Gait variability and the risk of incident mobility disability in community-dwelling older adults. J Gerontol A Biol Sci Med Sci. 2007;62(9):983-8.

14. Najafi B, Helbostad JL, Moe-Nilssen R, Zijlstra W, Aminian K. Does walking strategy in older people change as a function of walking distance? Gait Posture. 2009;29(2):261-6.
15. Callisaya ML, Blizzard L, Schmidt MD, McGinley JL, Srikanth VK. Ageing and gait variability: a population-based study of older people. Age Ageing. 2010;39(2):191-7.

16. Guimarães RP, Alves, DPL, Silva GB, Bittar, ST, Ono NK, Honda E, et al. Tradução e adaptação transcultural do instrumento de avaliação do quadril Harris Hip Score. Acta Ortop Bras. 2010;18(3):142-7.

17. Bellamy N, Buchanan WW, Goldsmith $\mathrm{CH}$, Campbell J, Stitt LW. Validation study of WOMAC: a health status instrument for measuring clinically important patient relevant outcomes to antirheumatic drug therapy in patients with osteoarthritis of the hip or knee. J Rheumatol. 1988;15(12):1833-40.

18. Slaven EJ. Prediction of functional outcome at six months following total hip arthroplasty. Phys Ther. 2012;92(11):1386-94.

19. Bahl JS, Nelson MJ, Taylor M, Solomon LB, Arnold $\mathrm{JB}$, Thewlis D. Biomechanical changes and recovery of gait function after total hip arthroplasty for osteoarthritis: a systematic review and meta-analysis. Osteoarthr Cartil. 2018;26(7):847-63.

20. Fernandes MI. Tradução e validação do questionário de qualidade de vida para osteoatrose Womac (Western Ontario McMaster Universities) para a língua portuguesa [master's thesis]. São Paulo: Universidade Federal de São Paulo; 2002.

21. Kang HG, Dingwell JB. Separating the effects of age and walking speed on gait variability. Gait Posture. 2008;27(4):572-7.

22. Dingwell JB, Marin LC. Kinematic variability and local dynamic stability of upper body motions when walking at different speeds. J Biomech. 2006;39(3):444-52.

23. Sicard-Rosenbaum L, Light KE, Behrman AL. Gait, lower extremity strength, and self-assessed mobility after hip arthroplasty. J Gerontol A Biol Sci Med. 2002;57(1):M47-51.

24. Söderman P, Malchau H. Is the Harris hip score system useful to study the outcome of total hip replacement? Clin Orthop Relat Res. 2001;(384):189-97. 
25. Ejzenberg S. Tempo de vermelho intermitente/piscante em semáforos de pedestres, segundo o CTB - Código de Trânsito Brasileiro - e a boa prática de segurança na engenharia de tráfego. Sinal de Trânsito. 2011 [cited 2019 Sept 2]. Available from: https://bit.ly/2lykUdW

26. Kang HG, Dingwell JB. Dynamics and stability of muscle activations during walking in healthy young and older adults. J Biomech. 2009;42(14):2231-7.

27. Edmunds CT, Boscainos PJ. Effect of surgical approach for total hip replacement on hip function using Harris Hip scores and Trendelenburg's test. A retrospective analysis. Surgeon. 2011;9(3):124-9.

28. Harris K, Dawson J, Gibbons E, Lim CR, Beard DJ, Fitzpatrick R, et al. Systematic review of measurement properties of patient-reported outcome measures used in patients undergoing hip and knee arthroplasty. Patient Relat Outcome Meas. 2016;7:101-8.
29. Berend ME, Ritter MA, Harty LD, Davis KE, Keating EM, Meding JB, et al. Simultaneous bilateral versus unilateral total hip arthroplasty an outcomes analysis. J Arthroplasty. 2005;20(4):421-6.

30. Colo E, Rijnen WH, Gardeniers JW, van Kampen A, Schreurs BW. Satisfying results of primary hip arthroplasty in patients with hip dysplasia at a mean followup of 20 years. Clin Orthop Relat Res. 2016;474(11):2462-8.

Received in $10 / 15 / 2018$

Recebido em 15/10/2018

Recibido en 15/10/2018

Approved in 07/22/2019

Aprovado em 22/07/2019

Aprobado en 22/07/2019 